\title{
FIXED-TERM EMPLOYMENT CONTRACT IN THE SPHERE OF EDUCATION: THE ISSUES OF LEGAL REGULATION
}

\author{
Khrystyna Horuiko ${ }^{1}$, Mariia Muzyka ${ }^{2}$, Marianna Kokhan ${ }^{3}$ \\ ${ }^{1}$ Ph.D., Teacher, Faculty of Law, Uzhhorod National University, Uzhhorod, Ukraine, email: \\ avrora78@ukr.net \\ ${ }^{2}$ Ph.D., Associate Professor, Department of theory of law and criminal procedure activity, The Law \\ Enforcement Faculty, National Academy of the State Border Guard Service of Ukraine named after Bohdan \\ Khmelnytskyi, email: m-muzika@ukr.net, ORCID: https://orcid.org/0000-0002-4933-7101 \\ ${ }^{3}$ Ph.D. in Economics, Associate Professor, Department of Management, Faculty of Economics, Ivan Franko \\ National University of Lviv, email: marianna.kokhan@gmail.com, ORCID: https://orcid.org/0000-0002- \\ 9358-2200
}

Abstract. The provision of appropriate function of education sphere is treated as one of priority state tasks, $s$ an important structural element of quality educational services provision. The development of Ukraine state education policy should suppose the fact that all issues related to legal regulation ( forming of education legislation, defining the conditions of fixed term and labour contracts conclusion, development of legal means and organization evens for quality educational services provision) are solved in complex. The aim of this article is to research the issues of legal regulation of fixed term employment contract in the sphere of education. Research methodology: methods of logical comparison, systematization and generalization, general scientific and special research methods, in particular analysis and synthesis, system-structural analysis, which allowed to achieve the research goal. The importance of development is an appropriate, consistent state educational policy, focused on obtaining a qualitatively new result in the field of education, which would correspond to the state and trends of the world educational society and generally accepted international and European standards in this field. State educational policy should be implemented in stages based on the use of organizational, legal and economic principles. At the first stage of implementation of the state educational policy it is necessary to consistently identify urgent problems in the system of functioning of educational institutions and management in general, as well as problems of legal regulation of fixed-term employment contracts in the field of education. services.

Keywords: fixed-term employment contract, education field, educational institutions, legal regulation, education field employe.

JEL Classification: I28, I21, J83, J81, K31

Formulas: 0; fig.: 0; tabl.: 1; bibl.: 15

Introduction. Assessing the effectiveness of educational institutions and the quality of educational services is considered the main target function of the education system worldwide, where programs to assess the quality of educational services are set in the provisions of national education policy are implemented and functioning, and have a positive impact on education. The main trend of improving the education system is to shift the priority from maximum savings of public expenditures in the provision of educational services to the maximum efficiency of the resources involved. And this approach is relevant for educational institutions of Ukraine.

In modern conditions, the progressive development of the state is impossible without the constant improvement of the system of education and science, which is provided by employees in the field of education. Clear legal regulation of labor relations with employees in the field of education will facilitate the admission to the education and science system of highly qualified personnel only. Since the right to 
conduct activities is one of the main social constitutional rights of the individual: therefore the optimal state of legal regulation of the activities of this category of workers will ensure the effective implementation of this right. The growth of the number of competitive specialists, which guarantees the receipt of quality, thorough education, is realized through the activities of employees in the field of education.

Literature review. A significant number of scientists study the subject of the educational field and the effective work of educational institutions. In particular, the scientific works of VA Kononenko [5], V. Ya. Kiyan [3], DO Kiva [2], K. PopovaKoryak [7], N.G. Moskalyk [6], S O. Silchenko [14], Yu. P. Dmytrenko [2] are devoted to the analysis of some aspects of formation of normative legal acts in the modern educational branch of Ukraine in frames of globalization processes and challenges which have influenced development and formation of activity of educational institutions. Currently, the implementation of regulations in the field of education remains insufficiently studied, so the analysis of scientific achievements of researchers gives grounds to assert the existence of different approaches in the study of this issue.

Aims. The purpose of the article is to outline the problems of legal regulations in terms of reforming the education sector and identify the main problems in concluding fixed-term employment contracts. Identify the main aspects of concluding and regulating the current legislation of the country fixed-term employment contracts in the field of educational activities. To compare the national normative-legal regulation of fixed-term employment contracts in the field of educational activity with the normative-legal regulation in other countries of the world.

Methods. The author used methods of logical comparison, systematization and generalization, general and special research methods, including analysis and synthesis, system-structural analysis, which allowed to achieve the goal of the study.

Results. Reform of education and labor legislation in accordance with the declared vector of accession to the European Union, where this process is quite intensively implemented by the country in recent years. As noted by Popova-Koryak $\mathrm{K}$. legal regulation of employees in the field of education, on the implementation of the main socio-economic human rights - law, which is the primary element of the formation of all relations in the field of employment - the right to work, requires a detailed study of the implementation of the right to work by scientific and pedagogical workers in the form of a fixed-term contract. In accordance with the transformed changes in the legislation on higher education, which in turn has led to a change in the legal regulation of the implementation of the right to work of workers in the field of education [7, p. 80].

Specific traits of the legal regulation of labor relations with research and teaching staff and employees of higher education institutions is a combination of their centralized regulation with the local, which is modified by each educational institution separately. The main legal act that guarantees the legal regulation of labor relations in the field of education with research and teaching staff is the Labor Code of Ukraine (hereinafter - the Labor Code of Ukraine) [4]. According to the country's legislation, labor relations with research and teaching employees require extravagant 
legal regulation, which is poorly defined and not provided by the Labor Code of Ukraine, which defines only universal provisions that do not take into account the current nature of labor relations with workers in education and science. This uncertainty has led to the formation and implementation of a number of special regulations, where the first special regulations, defining the general provisions regarding the regulation of labor relations of educators, is the Law of Ukraine № 2145-VIII from 05.09.2017 "On Education" [9], where this law regulates the universal rights and responsibilities of workers in education, determines state guarantees for this category of workers, sets requirements for education and professional qualifications of workers in education sphere, their professional development and the procedure for improving the professional specialization of research and teaching staff, regulates working hours and wages of this category of employees.

According to Part 11 of Art. 55 of the Law of Ukraine "On Higher Education" [8] defines that the Academic Council of educational institutions should develop a procedure for competitive selection when filling vacancies in education and concluding fixed-term employment contracts with them, also recognized Recommendations for competitive selection when filling vacant positions of employees in the field of education and concluding fixed-term employment contracts with them, which are approved by the enactment of the Ministry of Education and Science of Ukraine 05.10.2015 № 1005 [13]. Given that a number of amendments to the laws of Ukraine have been made at the present stage, has resulted that these recommendations require revision and amendments. According to the analysis, Kononenko VA notes that these Recommendations define the norm regarding the conclusion of a fixed-term employment contract for a period of 5 years when hiring in higher education institutions as a result of a successful competition to replace an employee in education sphere. This norm is absent in the Law "On Higher Education" and is considered to be contrary to international labor law standards [5, p. 89-90].

Dmytrenko Yu. P. and Kiva D.O. indicate that the characteristic features of a fixed-term employment contract is that it is concluded for the relevant term, which is defined and stipulated in this contract. The essence of this fixed-term contract is that it is not a form of employment contract, as stated in Part 3 of Art. 21 of the Labor Code of Ukraine, and is a specific type [2, p. 133].

In order to determine the characteristics of fixed-term employment, it is likely in the case of establishing the division of employment contracts into perpetual and fixed-term ones. For the former, the characteristic condition is the conclusion of an ordinary employment contract, where the contract must be understood as a contract that is concluded without a fixed term, and which is not limited to the time of the relevant activity or in the event of a certain situation.

With regard to fixed-term employment relationships that appear on the basis of signing and concluding a fixed-term employment contract which is limited in time and this term is defined in the contract. Thus, the most important characteristic feature of fixed-term employment is their emergence on the basis of a fixed-term employment contract. 
Moskalyk N.G. provides an interpretation of a fixed-term employment contract, as a legal fact that gives rise to the appropriate type of relationship, which for some types of fixed-term employment contracts is signing and concluding a fixed-term employment contract is not sufficient where in this case there is a factual composition.Meaning that it consists of several intermediate legal facts, which in general are the basis for the emergence of fixed-term employment [6, p. 125].

Therefore, the basis for the emergence of fixed-term employment in these cases is a fixed-term employment contract, which was preceded by other legal consequences: the act of election, order of appointment or competitive selection, where the latter is a prerequisite for its conclusion. The emergence of fixed-term employment relationships with the actual composition occurs when elected to office; appointment; competitive replacement of a vacant position and in other cases.

A fixed-term employment contract is inextricably linked to the category of term, where it is necessary to investigate the characteristics of the term in fixed-term employment. In accordance with the objective and subjective moment determined by S.O. Silchenko [14, p. 13], namely the dual nature of the term requires the expediency of its study from two sides: as a legal fact-event and as a legal fact-action. A specific trait of the term as a legal fact-action is that the parties to a fixed-term employment relationship have the opportunity to choose its duration, except when the legislator centrally prohibits reducing or increasing the term, this procedure occurs when concluding a contract with the head of a state enterprise. should be five years old.

The term of a fixed-term contract as a legal fact-event is interrelated with its objective nature, which is manifested in the inability to influence its current course, except when the parties terminate the fixed-term employment relationship on their own initiative. Moskalyk N.G. notes that the term is a prerequisite for the emergence of fixed-term employment, because they can not exist without its establishment [6, p. 127].

Labor relations for a scientific and pedagogical employee of an educational institution appear on the basis of an employment contract. The Law of Ukraine № 2145-VIII contains a provision on the application of a contract which provides for the signing and conclusion only with the heads of educational institutions, where the contract, in accordance, is a fixed-term employment contract. In Art. 21 Labor Code of Ukraine, the contract is a specific form of employment contract, in which its term, rights, duties and responsibilities of the parties, as well as taking into account liability, conditions of material insurance and organization of the employee, as well as conditions for termination of fixed-term contract, including early, are established by agreement of the parties.

The purpose of the contract in accordance with the resolution of the Cabinet of Ministers of Ukraine "On streamlining the application of the contractual form of employment contract" of March 19, 1994 № 170 is the insurance of conditions for the positive characteristics of the employee, which takes into account his professional abilities and personal skills. legal and social protection of the employee. However, these conditions in practice usually lead to a violation of the rights of employees, 
rather than to stimulate their professional activities. In accordance with this resolution Kononenko V.A. identified the characteristics of the contract and the specifics of its content, which is broader, compared with the content of the employment contract [5, p. 92].

According to the established norm of the law, the parties to a fixed-term contract have the opportunity to establish by agreement their rights, obligations and increased liability. According to Art. 36 of the Labor Code of Ukraine establishes the grounds for termination of a fixed-term employment contract, which the employer does not have the opportunity to supplement or amend. A specific feature of a fixed-term employment contract is the probability of establishing by the parties on the basis of the agreement of the adventitious grounds for its termination, which are not defined in the said article of this law. Thus, in fact, the parties are entitled to nullify a fixedterm employment relationship on the basis of a fixed-term employment contract both on general grounds and on the grounds specified directly by their agreement and specified in the fixed-term employment contract. Kiyan V. Ya. points out that these conditions often violate the rights of employees, which causes the likelihood of labor disputes in connection with the illegality of the grounds for termination of a fixedterm employment contract [3, p. 45].

Due to the rather low level of legal regulation of concluding a fixed-term employment contract at the legislative level and in practical implementation, there are problems with the use of this legal institution. Therefore, it is necessary to define in the Law of Ukraine "On Higher Education" cases concerning the conclusion of a fixed-term employment contract and a contract [8]. An analysis of the current Draft Labor Code was conducted by V.Ya. Kiyan, who determined that this Draft does not provide for the form of a fixed-term employment contract as a contract, which raised doubts about the expediency of its existence [3, p. 46]. Also, Kononenko V.A. determined that the main problem is the lack of a defined detailed list of essential conditions of the contract, where some of them are specified in Chapter. 3, Art. 21 of the Labor Code of Ukraine, namely: the conditions of material insurance and organization of the employee; conditions of contract rejection; term of the contract; rights, duties and responsibilities of the parties [5, p. 92].

Analyzing the scientific and pedagogical activity, the characteristics and conditions of its implementation does not provide a clear basis for determining fixedterm employment in terms of the content of work. Because, this type of activity is concentrated on thorough, fundamental results of activity, which are possible on the basis of stable, uninterrupted activity only. Only in these conditions the employee will provide high performance, and the term of his activity can be set in the event that the employee insists on the appointment of a term.

At this stage of existence, the legal consequences of signing and concluding a fixed-term employment contract with research and teaching staff are obvious and defined in Chapter. 3 point 9 of the Resolution of the Plenum of the Supreme Court of Ukraine of November 6, 1992: "After all, in accordance with Part 2 of Art. 23 of the Labor Code fixed-term employment contract may be concluded only if the fixedterm employment relationship for an indefinite period can not be determined, due to 
the specific features of the activity or conditions of its implementation, or the relevant interests of the employee, or in other cases provided by law , therefore, the signing of a fixed-term employment contract for a specified period in case of insufficiency of these conditions is the basis for its invalidation in terms of determining the term "[10].

Therefore, the specified provision of the Recommendations on concluding fixedterm employment contracts should be such that it does not contradict the current legislation, because at the present stage higher education institutions reproduce these instructions in their Competition Regulations as a result of further deepening violations of international acts. and the Labor Code of Ukraine. Some higher education institutions in the country define the following Regulations: to establish other conditions of the contract by agreement of the parties in accordance with the established legislation of the country ". According to the current Law of Ukraine "On Higher Education", the contract is concluded exclusively with management positions, namely with the head of higher education, head of the faculty (educational and scientific institute), head of the department [8].

In these cases, the implementation of the autonomy of higher education institutions in connection with the likelihood of individual development and adoption of its Regulations on the selection of employees in the field of education, which contains the opposite results of the main goal of educational reform. education.

Therefore, in the context of the study of this issue there is a need to periodically check the compliance of the professional specialization of the employee in the field of education. The competition procedure should be used exclusively as a procedure to verify the applicant's compliance with the requirements set for an employee in the field of education exclusively for vacant positions. In the event that the position is not vacant, the law prohibits the artificial formation of the position while concluding fixed-term employment contracts. It is necessary to apply the certification procedure to employees in this field every 5 years.

Thus, the competition will achieve a specific goal, namely the selection of the best candidates for the position, and the certification will confirm the compliance of the employee in the field of education to the position. We propose to supplement Part 12 of Art. 55 of the Law of Ukraine "On Higher Education" [8] with the following paragraph: "employees in the field of education are required to undergo certification, which determines the compliance of employees with the position every five years."

We propose to correct and supplement in a similar way the references in the Recommendations and the Law of Ukraine "On Education". In the case of certification, an employee in the field of education will be recognized as not meeting the requirements of the position, as a result of insufficient professional specialization, which prevents the continuation of this activity, where in this case to dismiss the employee under paragraph 2 of Art. 40 of the Labor Code of Ukraine [4], where these references must be spelled out in detail in the Recommendations. The current state of recruitment in the field of education is inextricably linked with the reform and modernization of this area. After all, thanks to the reform of the education sector, the 
competition procedures and in general the selection of staff for positions have been regulated.

Also, the Draft Labor Code of Ukraine changes the legislator's view on the basic provisions of fixed-term employment contracts. Thus, in paragraph 8 of Part 1 of Art. 58 of the Draft Labor Code of Ukraine states that employment relations for a specified period are determined with employees in the field of education, where the enrollment procedure is carried out in accordance with the law and the relevant results of the competition for a specified period [11].

On the basis of the Communique of the World Conference on Higher Education - 2009 "New dynamics of higher education and science for social change and development" signed by Ukraine, we strongly disagree with the enrollment procedure, carried out in accordance with the law and the relevant results of the competition for a specified period. recognized that "ensuring quality education requires recognition of the importance of attracting and maintaining a highly qualified and professional scientific and pedagogical staff" [1]. Thus, the conclusion of fixed-term employment contracts will not help to maintain a proper scientific and pedagogical staff.

Prudnikov V.A. studied the normative legal acts in force in the countries of the international educational space, which establish the rules of mandatory requirements for the conclusion of fixed-term employment contracts. In Italy, fixed-term employment contracts stipulate that the head of an educational institution is obliged to provide his employee with a written document when hiring, which must specify the conditions of this type of activity by agreement of the parties. In the labor law of Germany there is a principle of freedom of contract, which establishes that the parties are free to include in the employment contract all issues related to the activities of the employee in this area of activity. In particular, in France and Italy in the legislation in the content of the fixed-term contract such essential conditions, as, duration of working hours, working week, holidays can be included.

US federal and state laws govern the following terms of a fixed-term contract: the minimum wage, the maximum term of the fixed-term contract, the procedure for payment of wages, working hours during the week, types of rest, the minimum duration of annual leave, mandatory overtime. urgent

Croatian law obliges to include in the fixed-term contract information about the specialty, profession, level of professional specialization of the employee and other requirements regarding his professional abilities. The contract determines the day of employment, the duration of working hours, the probationary period, the amount of salary, the duration of the annual main and additional leave, other rights and obligations of the parties.

According to the legislation on the activities of employees in the field of education in the Czech Republic, the employer is obliged to agree with the employee in a fixed-term contract the following essential conditions: type of work; place of performance of work (settlement, structural subdivision or other specific place); start date [12, p. 382-383]. 
It is worth noting among the countries of Western Europe the French Republic (hereinafter - France), because it is the largest territory among other European countries, so undoubtedly, the analysis of the legal regulation of the conclusion, amendment and termination of employment contracts in France is very relevant and appropriate for formation of a general idea of the development of the category of employment contracts in the world. The comparison of the regulations of Ukraine and France (Table 1) $[4 ; 15]$.

Table 1. Legal regulation of fixed-term employment contracts in the sphere of education in Ukraine and France

\begin{tabular}{|c|c|c|}
\hline Specific trait & Ukraine & France \\
\hline $\begin{array}{l}\text { Fixed- term employment } \\
\text { contacts regulation }\end{array}$ & Labour code & Labour code \\
\hline $\begin{array}{l}\text { Presence of chapter in Labour } \\
\text { code related to fixed-term } \\
\text { employment contracts } \\
\text { regulation }\end{array}$ & Chapter III available & No Chapter \\
\hline Division of labour contracts & $\begin{array}{l}\text { Three types of labour contracts } \\
\text { such as perpetual, for fixed } \\
\text { term, which is concluded for } \\
\text { specific work performance. }\end{array}$ & $\begin{array}{l}\text { Two types of labor contracts } \\
\text { such as perpetual labour } \\
\text { contracts and labour contract } \\
\text { for fixed term: }\end{array}$ \\
\hline $\begin{array}{l}\text { Division of fixed-term labour } \\
\text { contracts }\end{array}$ & No division & $\begin{array}{l}\text { Sub-types of fixed term labour } \\
\text { contract: labour contract for } \\
\text { part time job; labour contract } \\
\text { prompting work renewal; agent } \\
\text { labour contract, labour contract } \\
\text { fo persons aged } 57 \text { and looking } \\
\text { for a job for more than three } \\
\text { months; labour contract for } \\
\text { workers aged 16-25 related to } \\
\text { their further employment. }\end{array}$ \\
\hline $\begin{array}{l}\text { Terms of fixed-term labour } \\
\text { contracts }\end{array}$ & $\begin{array}{l}\text { The fixed-term labour contract } \\
\text { can be cocluded for one day } \\
\text { only; while the law does not } \\
\text { interfere with labour contract } \\
\text { conclusion for } 3,5,10 \text { or } 20 \\
\text { years. }\end{array}$ & $\begin{array}{l}\text { The general term of fixed term } \\
\text { labour contract should not } \\
\text { exceed one year and half. }\end{array}$ \\
\hline $\begin{array}{l}\text { Legal ground for contract } \\
\text { conclusion with instructors }\end{array}$ & $\begin{array}{c}\text { Article } 54 \text { of the Law "About } \\
\text { education". }\end{array}$ & Labour law \\
\hline Education norms & $\begin{array}{l}\text { Uppers norms of educational } \\
\text { load for one position make } 600 \\
\text { hours a year. }\end{array}$ & $\begin{array}{c}\text { From } 128 \text { to } 384 \text { hours a year } \\
\text { depending of instructor } \\
\text { category }\end{array}$ \\
\hline $\begin{array}{l}\text { Type of contracts in the } \\
\text { sphere of education }\end{array}$ & Perpetual contracts prevail & Perpetual contracts prevail \\
\hline State employee status & $\begin{array}{l}\text { The status is not provided, while } \\
\text { state employees have the right to } \\
\text { work as instructors part-time }\end{array}$ & $\begin{array}{l}\text { The status is provided to senior } \\
\text { instructors and professors as } \\
\text { these are two highest academy } \\
\text { categories. Junior instructors } \\
\text { are not covered }\end{array}$ \\
\hline
\end{tabular}

Sourses: made on the basis of the following references: [4; 15] 
Thus, French labor law is one of the most focused on the protection of workers interests, compared to Ukraine, as the Labor Code contains significant types of fixedterm contracts, each containing relevant rules and protection of workers' rights, optimal teaching standards for workers in education, and civil servant status is also granted to senior teachers and professors. Therefore, borrowing the positive aspects of the French labor law model in the further reform of labor legislation of Ukraine is appropriate.

Thus, international regulations do not pursue the goal of regulating fixed-term employment in their entirety, in determining all the conditions of activity in the field of education.

Discussion. Analyzing the current state of modern legal regulation of fixed-term employment relations with employees in the field of education, its main issues were identified. As the Law on Higher Education gave higher education institutions independence in resolving a large number of issues, general education institutions were not given such an opportunity, so labor relations in this area require the application of the principle of combining local regulation with centralized. Therefore, the following rules should be implemented: the main requirements for candidates for the position of employee in the field of education should be supplemented by the requirement to have high moral qualities and the condition of proper physical and mental health; to form significant conditions regarding the fixed-term and employment contract at the legislative level; to establish the legal definition and purpose of competitive selection for the position of an employee in the field of education, and to approve the main cases when concluding an employment contract without announcing a competition.

Conclusion. Thus, fixed-term employment relationships have speicifc traits that are inherent in ordinary employment relationships, as they are a generic concept in relation to the former. As types of concepts, fixed-term employment has its own characteristics, which is a fixed-term employment contract as a basis for their formation; where their subjects are the employee with whom the fixed-term employment contract was concluded and the employer who uses his work; this type of work is temporary, and in some cases focused on achieving a certain result of work, as well as the specific content that is provided at the legislative or local level.

The main provisions concerning the regulation of fixed-term employment of employees in the field of education should be separated in a separate section of the Law of Ukraine "On Higher Education" and "On Education" entitled "Labor relations with employees in the field of education", which should define standards for candidates education; the main conditions of the fixed-term and employment contract; delimitation of the basis of their conclusion; characteristic features of competitive selection; main rights and responsibilities of employees; basic provisions regarding their certification, their working hours and remuneration in the field of education; as well as legislation on material incentives for employees. The implementation of these proposals will help to form an appropriate legal basis for the optimal functioning of the system of fixed-term and employment relations with employees in the field of education. 
Thus, as a result of the study it was determined that in modern conditions there is no appropriate regulatory and legal support for the formation of fixed-term employment contracts in the field of education. As 2020 is a turning point for this stage of reform, where in early 2021, it will be possible to see whether the government has been able to remove existing obstacles in the system of formation of fixed-term employment contracts in education, because these obstacles can have negative consequences for quality assurance. and availability of educational services.

Author contributions. The authors contributed equally.

Disclosure statement. The authors do not have any conflict of interest.

\section{References:}

1. International document (2009), World Conference on Higher Education - 2009 "New dynamics of higher education and science for social change and development": International document, 8 July, 2009-r, retrieved from: http://zakon3.rada.gov.ua/laws/ show/952_011.

2. Dmytrenko Yu. P., Kiva D. O. (2016), Kontrakt yak osoblyvyi vyd dohovoru pro pratsiu (sotsialnopravovyi aspekt) [Contract as a special type of employment contract (socio-legal aspect)], Journal of Kyiv University of Law. № 1. pp. 131-135, retrieved from: http://nbuv.gov.ua/UJRN/Chkup_2016_1_31.

3. Kiyan V. Ya. (2016), Osoblyvosti zastosuvannia kontraktnoi formy trudovoho dohovoru $z$ naukovopedahohichnymy pratsivnykamy [Features of application of the contractual form of the employment contract with scientific and pedagogical workers], State and regions. Series: Right. №2 (52). pp. 45-46.

4. The Verkhovna Rada of Ukraine (1971), The Law of the Ukrainian SSR " Code of Labor Laws of Ukraine", 10 December, № 322-VIII, 1971-r, retrieved from: http://zakon3.rada.gov.ua/laws/show/32208/page5.

5. Kononenko V.A. (2018), Stan pravovoho rehuliuvannia trudovykh vidnosyn z naukovo-pedahohichnymy pratsivnykamy: aktualni problemy ta shliakhy vdoskonalennia [The state of legal regulation of labor relations with research and teaching staff: current issues and ways to improve], Prykarpattya Legal Bulletin. №. 1 (22). Volume 2. pp. 89-94.

6. Moskalyk N.G. (2009), Osoblyvosti strokovykh trudovykh pravovidnosyn yak vydu trudovykh pravovidnosyn [Features of fixed-term employment as a type of employment], Current issues of state and law: Collection of scientific works. Odessa: Jurid. 1-ra. № 46. pp. 123-130.

7. Popova-Koryak K. (2017), Osoblyvosti realizatsii prava na pratsiu naukovo-pedahohichnykh pratsivnykiv: suchasnist i perspektyvy pravovoho rehuliuvannia kriz pryzmu mizhnarodnykh standartiv prav liudyny [Features of the right to work of scientific and pedagogical workers: modernity and prospects of legal regulation through the prism of international human rights standards], Entrepreneurship, economy and law. № 11. pp. 79-84.

8. The Verkhovna Rada of Ukraine (2014), The Law of Ukraine "On higher education", 1 July, № 1556-VII, 2014-r, retrieved from: http://zakon.rada.gov.ua/laws/show/1556-18.

9. The Verkhovna Rada of Ukraine (2014), The Law of Ukraine "On education", 5 September, № 2145VIII, 2017-r, retrieved from: http://zakon.rada.gov.ua/laws/show/2145-19.

10.The Verkhovna Rada of Ukraine (2014), Resolution of the Supreme Court of Ukraine "On the practice of consideration of labor disputes by courts", 6 November, № 9, 1992-r, retrieved from: http://zakon2.rada.gov.ua/laws/show/v0009700-92.

11.The Verkhovna Rada of Ukraine (2019), Draft Labor Code of Ukraine, retrieved from: http://w1.c1.rada.gov.ua/pls/zweb2/webproc4_1? pf3511=53221.

12.Prudnikov V.A. (2012), Oboviazkovi umovy trudovoho dohovoru v Ukraini ta zarubizhnykh derzhavakh: sproba porivnialno-pravovoho analizu [Mandatory terms of the employment contract in Ukraine and foreign countries: an attempt at comparative legal analysis], Current issues of state and law. № 63. pp. 379-384? retrieved from: http://nbuv.gov.ua/UJRN/apdp_2012_63_57.

13.The office of the Ministry of Education and Science (2015), Order of the Ministry of Education and Science "Recommendations for competitive selection when filling vacant positions of research and teaching staff and concluding employment agreements (contracts) with them", 5 October, № 1005, 2015-r, retrieved from: http://zakon.rada.gov.ua/ rada/show/v1005729-15. 
14.Silchenko S.O. (2005), Strokovyi trudovyi dohovir za zakonodavstvom Ukrainy: poniattia, vydy, umovy ukladennia, zminy ta prypynennia [Fixed employment contract under the legislation of Ukraine: concepts, types, conditions of conclusion, changes and termination], Kharkiv. Golden Pages, p. 13.

15.Spitsyna, G.O. (2014), Zahalna kharakterystyka dzherel pravovoho rehuliuvannia trudovykh vidnosyn u Frantsuzkii Respublitsi, [General characteristics of the sources of legal regulation of labor relations in the French Republic]. URL: file: /// C: /Users/111/Downloads/vchfo_2014_4_15.pdf.

Received: September 25, 2020

Approved: October 20, 2020 